\title{
A hedonic response to an assay made on octogenarians using cosmetics that promise to donate comfort, attractiveness and youth
}

\section{Lorenzo Martini}

University of Siena, Department of Pharmaceutical Biotechnologies, Via A. Moro 2, 53100 Siena, Italy

Corresponding author: Lorenzo Martini, M.Sc., E-mail: martinil163@libero.it

\begin{abstract}
I have been formulating cosmetics for thirty years and We am deeply conscious that Senescence is an irreversible physiological phenomenon and the unique way to escape decline is prevention (by using drastic moisturizers since early age or the camouflage in elderly or just before male climacteric or menopause), as famous Empresses did in XVI and XVII century. Purpose of this odd study is to disclaim a revolutionary method to investigate upon the "hedonic response" only septuagenarians and octogenarians, living in luxury a rest home, may display after having used natural cosmetics with the clear advertising that they are only remedies apt to let them feel younger, attractive and active. The volunteers were invited to respond to simplest questionnaire about satisfaction, according to the Peyram's hedonic test.
\end{abstract}

Key words: Xerosis; Pruritus; Senescent skin; Eczematous dermatitis; Purpura; Peyram’s hedonic test

\section{INTRODUCTION}

Four are the chief aesthetical manifestations occurring and therefore valuable to be studied in the interesting and ignored and disregarded field of the geriatric dermatology [1-4].

Xerosis which occurs most often on the hands and all throughout the entire trunk. The appearance of xerotic skin is like a pattern of cracked pottery. These cracks or fissures are present owing to the progressive epidermal water loss (TEWL).

Pruritus: the characteristic patterns of pruritus in elderly include scratching and inflammation. The condition is often associated with other underlying diseases. Itching is reputed to be induced by the effect of histamine and is mediated exclusively by the peripheral nervous system.

Eczematous Dermatitis: Asteatotic eczema, nummular eczema, seborrheic dermatitis, gravitational eczema, and autoeczematization eczema fall under the category of eczematous dermatitis in the elderly.

Purpura: that can be defined as any of a group of conditions characterized by ecchymoses or other small hemorrhages in the skin, mucous membranes, or serosal surfaces. Purpura may be caused by decreased platelet counts (thrombocytopenia), platelet abnormalities, vascular defects, trauma, or drug reactions.35 Elderly persons are especially susceptible to hemorrhage into the skin.

Two are the seats where malaises and dysfunctions currently appear in old people: epidermis and derma.

And finally, two are the physiopathological metamorphoses which occur in epidermis and other two in dermal regions:

As far as epidermis is concerned a decrease of $14 \%$ of melanocytes is observed per decade, and as far as Langerhans cells are concerned it is undeniable

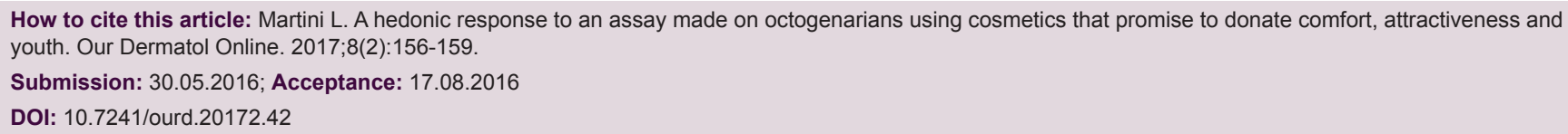


that their density and responsiveness decline progressively.

It is noticeable a - $1 \%$ dermal collagen collapse per year, and moreover (especially in female) collagen is calcified by Calcium ions originating from ostheoporosis, that include a severe Calcium loss from bones [5-17].

All the photo-inducted diseases are to be neglected in this paper, since the Author studied only old women living in a luxury rest home for old age persons, which are not supposed to stay too long exposed to sun rays: only one hour in the afternoon drinking fresh beverages under palms and beeches, so that they cannot manifest actinic keratoses, telangectasias and pigmentary disorders.

My attention was focused only on the black spots every beldam cannot hid.

In effect aim of my research has been to fit out a sensorial hedonic questionnaire to old ladies (16 individuals from 76 to $91 \mathrm{y}$ ) who live together in a rest house in a lovely and calm champaign.

They had solely to respond to a series of questions (twelve questions) about the satisfaction after having used creams and alcohol-free lotions containing certain peculiar plants with diverse functions and attitudes apt to struggle the aforesaid manifestations, typical of elderly.

The experimentation lasted 7 days.

Questions were extremely simple and reasonable, like: How do You feel today?

Do You feel your skin oiled?

Do You feel a sensation of a silky or velvety skin? How many times do You need to scratch your trunk? and so on.

I retained no approval of the study by the Local Ethical Committee was required and therefore I have thought that it is utterly superfluous to find out an approval number and the corresponding date to provide to the Editor, even because all the treated individuals, had previously accepted voluntarily to try the suggested cosmetic items, by herbs that are all included in INCI.

To try to defeat the four chief aesthetical manifestations occurring in geriatric dermatology, four are the type of plants that contain manifold principles that synergically contribute to the full resolution of the problem.

First of all: Anti-inflammatory remedies are required for combat eczematous dermatitis: and they are represented by all kinds of plants containing antioxidants and polyphenols, catechins and anthocyanines (turmeric, green tea, white willow bark, maritime pine).

Herbs containing high percentages of saponines and sapogenines are required to fight xerosis and hyperkeratosis as well. (Dioscorea villosa (Wild Yam), Panax ginseng (Chinese or Korean Ginseng), Glycyrrhiza glabra (Licorice), Smilax sp. (Sarpsarilla) Convallaria majalis (Lily of the Valley)

Plants containing anesthetic principles (Mandrak, Lobelia, Pau d'Arco,Caraway) are useful to combat pruritus.

Abstringent herbs containing gallates, tannins (Barley Grass (Oryza sativa leaf extract, CAS

68553-81-1, Boneset (Eupatorium cannabinum extract, CAS 84625-34-3, Catauba (Erythroxylum catauba bark extract), Chanca Piedra (Saxifraga sarmentosa extract), Eleutero root, and all plants belonging to Cyclopia spp. especially Cyclopia Genistoides leaf extract, CAS 85940-31-4) and others containing immunostimulants are excellent to struggle purpura. (Achillea millefolium (Yarrow), Aesculus hippocastanum (Horeschesnut), Capsella bursa-pastoris (Shepard's Purse), Hamamelis virginicus (Witch Hazel).

Ointments must be always prepared as ancient Pharmacopoeias prescribed, using all animal greases (seal, reindeer, shark, pig, ox or sheet) and amongst those the ones which present the major percentage of $\omega-6$ acids.

Paladins of the Organic Cosmetology are thus prayed to put definitively off the diatribe about the animals' sacrifice to obtain certain greases and fats, whenever, they are prayed to shrink whichever automotive machine (forecasted for the production of manifold consumer good,) that all use animal greases as main lubricants low cost, according to Rule CE 1069/2009, and Rule UE 142/2011.

All this, because these greases and animal fats are utterly diachysic bio-principles with regards to injured and senescent skin. 


\section{MATERIALS AND METHODS}

The 16 volunteers were classified as follows: Four ladies suffering from xerosis $(\mathrm{A}, \mathrm{B}, \mathrm{C}, \mathrm{D})$, four ladies suffering from pruritus (E,F,G,H), four ladies suffering from eczematous dermatitis $(\mathrm{I}, \mathrm{L}, \mathrm{M}, \mathrm{N})$ and finally four ladies suffering from purpura $(\mathrm{O}, \mathrm{P}, \mathrm{Q}, \mathrm{R})$ and all they were prayed to spread the following products four one week and to answer to the Peyram's questions twice a day.

1. An ointment made of glycolic extracts of Dioscorea villosa, Panax ginseng, Glycyrrhiza glabra, Sarpsarilla and Convallaria majalis (Lily of the Valley) for the 4 ladies suffering from xerosis.

2. An ointment made of glycolic extracts of Mandrak (Mandragora officinarum root extract, CAS 90063-85-7, Pau d'Arco (Tabebuia impetiginosa bark extract, CAS 90063-85-7, Caraway (Carum carvi fruit extract, CAS 85940-31-4 for the 4 ladies suffering from pruritus.

3. An ointment made of glycolic extracts turmeric, green tea, white willow bark, maritime pine for the 4 ladies suffering from eczematous dermatosis.

4. An alcohol-free lotion containing all the tinctures of all the aforesaid abstringent and immunostimulant herbs for the 4 ladies suffering from purpura.

The most widely used scale for measuring food and/ or cosmetic acceptability is the 9-point hedonic scale David Peryam and colleagues developed at the Quartermaster Food, Cosmetic and Toiletries and Container Institute of the U.S. Armed Forces, for the purpose of measuring the preferences of soldiers. The scale was quickly adopted by the food industry, and now is used not just for measuring the acceptability of foods and beverages, but also of personal care products, household products, and cosmetics.

The hedonic scale was the result of extensive research conducted at the Quartermaster and at the University of Chicago.

The Peryam's Point Hedonic Scale foresees the following nine responses:

9-Like Extremely

8-Like Very Much

7-Like Moderately

6-Like Slightly

5-Neither Like nor Dislike

4-Dislike Slightly

3-Dislike Moderately
2-Dislike Very Much 1-Dislike Extremely.

\section{RESULTS}

Each day we obtained two responses corresponding to the relative number of the scale.

The numerical differences were calculated as integer numbers, and this ought to correspond to the statistical part of all the experiment made in the rest home, and fortunately it has been fully possible to draw Table I where all the values are scored.

The higher is the value, the major is the feeling of satisfaction.

\section{DISCUSSIONS}

Somebody could object that the psychological approach to the experiment is important to evaluate the real degree of satisfaction: abandoned beldams could be exaggerate their appreciations on the donated products, since they feel, in that precise circumstance, important and loved for one entire week, as it were a joke.

The old ladies have always responded seriously and conscientiously to the Peyram's questionnaires.

\section{CONCLUSION}

The scores are sufficiently clear to show that there cannot be any doubt about the fact that too often

Table 1: Peyram's scores representing the single degee of each volunteer's satisfation

\begin{tabular}{lc}
\hline Subject-case & $\begin{array}{c}\text { Peryam's score (degree } \\
\text { of final satisfaction) }\end{array}$ \\
\hline A & 7 \\
B & 5 \\
C & 6 \\
D & 8 \\
E & 6 \\
F & 8 \\
G & 6 \\
H & 7 \\
I & 5 \\
L & 5 \\
M & 7 \\
N & 9 \\
O & 7 \\
P & 6 \\
Q & 8 \\
R & 7 \\
\hline
\end{tabular}


the lacquered World of Cosmetic lavishes illusions, howbeit they sometimes are not fake or misleading.

\section{ACKNOWLEDGEMENTS}

We am proud to declare officially that nobody helped me for this study or contributed to the scientific content or provided technical support. We got no sources of financial supports at all.

\section{REFERENCES}

1. Roberts WE. Generational dermatology: model of prevention and multi-decade approach to the evolving aging patient. In: J Drugs Dermatol. New York;12(12):pp 2013;1396-7.

2. Leavell HR, Clark EG. Preventive Medicine for the Doctor in his Community: An Epidemiologic Approach. 3rd ed. Huntington, NY: Robert E. Krieger Publishing Company 1979.

3. Kubiak M, Mucha P, Debowska R, Rotsztejn H. Evaluation of $70 \%$ glycolic peels versus $15 \%$ trichloroacetic peels for the treatment of photodamaged facial skin in aging women. Dermatol Surg. 2014;40:883-91.

4. Rubegni P, Poggiali S, Nami N, Rubegni M, Fimiani M. Skin diseases in geriatric patients: our experience from a public skin outpatient clinic in Siena. G Ital Dermatol Venereol. 2012;147:631-6.

5. Lewis DA, Travers JB, Spandau DF. A new paradigm for the role of aging in the development of skin cancer. J Invest Dermatol. 2009;129:787-91.

6. Lewis DA, Travers JB, Spandau DF. Aging-associated nonmelanoma skin cancer: a role for the dermis. In: Farage MA, Miller KW, Maibach HI. Eds. Textbook of Aging Skin. New York, NY: Springer; 2010:587-99.

7. Spandau DF, Lewis DA, Somani AK, Travers JB. Fractionated laser resurfacing corrects the inappropriate UVB response in geriatric skin. J Invest Dermatol.2012;132:1591-6.

8. Dewberry C, Norman RA. Skin cancer in the elderly. Dermatol Clin. 2004;22:93-6.

9. Clark CM, Furniss M, Mackay-Wiggan JM. Basal cell carcinoma: an evidence-based treatment update. Am J Clin Dermatol. 2014;15:197-216

10. Berking C, Hauschild A, Kölbl O, Mast G, Gutzmer R. Basal cell carcinoma-treatments for the commonest skin cancer. Dtsch Arztebl Int. 2014;111:389-95.

11. Micali G, Lacarrubba F, Nasca MR, Schwartz RA. Topical pharmacotherapy for skin cancer: part I. Pharmacology. J Am Acad Dermatol. 2014;70:965.

12. Glossman H. Vitamin D. UV, and skin cancer in the elderly: to expose or not to expose? Gerontology. 2011;57:350-3.

13. Trüeb, R. Oxidative stress in ageing of hair. Int J Trichology. 2009;1:6-14.

14. Christoffersen M, Frikke-Schmidt R, Schnohr P, Jensen GB, Nordestgaard BG, Tybjærg-Hansen A. Visible age-related signs and risk of ischemic heart disease in the general population: a prospective cohort study. Circulation. 2014;129:990-8.

15. Yang CC, Hsieh FN, Lin LY, Hsu CK, Sheu HM, Chen W. Higher body mass index is associated with greater severity of alopecia in men with male-pattern androgenetic alopecia in Taiwan: a crosssectional study. J Am Acad Dermatol. 2014;70:297-302.

16. Glynis A. A double-blind, placebo-controlled study evaluating the efficacy of an oral supplement in women with self-perceived thinning hair. J Clin Aesthet Dermatol. 2012;5:28-34.

17. Atanaskova Mesinkovska N, Bergfeld WF. Hair: what is new in diagnosis and management? Female pattern hair loss update: diagnosis and treatment. Dermatol Clin. 2013;31:119-27.

Copyright by Lorenzo Martini. This is an open access article distributed under the terms of the Creative Commons Attribution License, which permits unrestricted use, distribution, and reproduction in any medium, provided the original author and source are credited.

Source of Support: Nil, Conflict of Interest: None declared. 